\title{
FAMÍLIA E CASAL: FILIAÇÃO, INTERGERACIONALIDADE E VIOLÊNCIA
}

Julia Sursis Nobre Ferro Bucher-Maluschke

Universidade de Brasília

\section{Publicação}

Féres-Carneiro, T. (Org) (2019). Família e Casal: Filiação, Intergeracionalidade e Violência. Rio de Janeiro: Prospectiva/EDPUC-Rio.

\section{RESENHA}

O livro Família e Casal: Filiação, Intergeracionalidade e Violência, recémpublicado pelas Editoras Prospectiva/EDPUC-Rio, faz parte da coleção de livros sobre Casal e Família que vêm sendo publicados, a cada dois anos, com os resultados das pesquisas desenvolvidas pelos professores e pesquisadores membros do Grupo de Trabalho "Casal e Família: Estudos Psicossociais e Psicoterapia", coordenado pela Prof. Dra. Terezinha Féres-Carneiro, da Associação Nacional de Pesquisa e Pós-graduação em Psicologia-ANPEPP.

Neste livro, oriundo dos trabalhos apresentados no último simpósio ocorrido em Brasília, em julho de 2018, encontram-se resultados e reflexões de grande importância na atualidade sobre as questões da conjugalidade, da violência e intervenções que compõem a primeira parte do livro. A contribuição dos capítulos elaborados por pesquisadores integrantes do GT aborda a violência presente nas interações conjugais e aponta para a identificação da necessidade de uma educação conjugal, de um lado e, de outro lado, descreve ou apresenta a entrevista inicial no processo de psicoterapia de casal e de família em um serviço-escola de Psicologia; e, em outro capítulo, apresenta as dificuldades no manejo dos conflitos conjugais, seus motivos e suas soluções - contribui com ricas reflexões para todos aqueles interessados nos conflitos que podem gerar violências nas interações conjugais e familiares.

A segunda parte do livro trata das questões da parentalidade e filiação, e aborda aspectos tais como a construção dos vínculos afetivos em situação de adoção; como se tornar pais e filhos não biológicos; como conciliar a profissão da mulher e a vida familiar, assim como as consequências da guarda compartilhada de filhos em caso de separação conjugal; aborda comparativamente as dificuldades percebidas por pais e mães nas experiências do Brasil e do Uruguai e a reflexão teórica sobre as crianças parentalizadas na perspectiva do psicanalista Ferenczi e do mestre em transgeracionalidade Boszormenyi-Nagy.

$\mathrm{Na}$ terceira parte do livro são apresentados os resultados das pesquisas com o enfoque dos relacionamentos intergeracionais, enfatizadas as questões da 
individuação e da diferenciação em jovens, as interações entre idosos e adultos jovens e a família. Resultados de pesquisa sobre a revelação da homossexualidade na família e outros temas relacionados com as interações entre as gerações na própria família são discutidos. Também são trazidos nesta parte do livro outros temas relevantes relacionados com o espaço familiar. No seu conjunto, os capítulos, com seus conteúdos, nos permitem contemplar a constante busca do saber como um legado para o desenvolvimento profissional e o da pesquisa.

Além de trazer muitas referências teóricas e reflexões a partir da prática clínica, que certamente engrandecem a produção do conhecimento atinente às questões que enfrentam o casal e a família, o livro possibilita um despertar para a atuação clínica em face de tantos problemas árduos em nossos dias.

Sobre a autora

Julia Sursis Nobre Ferro Bucher-Maluschke graduou-se em Filosofia pela Pontifícia Universidade Católica do Rio de Janeiro (1964), Mestrado em Ciências Familiares e Sexológicas - Universite Catholique de Louvain (1969) e Doutorado em Ciências Familiares e Sexológicas - Universite Catholique de Louvain (1975). Título de Psicóloga pela Universidade de Brasília (1976). Realizou Pós-Doutorado na Alemanha - Universitat Tübingen (Tubingen, 1996) e nos Estados Unidos - St Johns University (NY 1988). Professora titular da Universidade de Fortaleza. Professora emérita da Universidade de Brasília em 2006. Especialização em Terapia Familiar. psibucher@gmail.com

Recebido em: 10/01/2020 Aceito em: $11 / 01 / 2020$ 